Copyright ( 2019 University of Bucharest Printed in Romania. All rights reserved

ISSN print: $1224-5984$

ISSN online: $2248-3942$
Rom Biotechnol Lett. 2019; 24(6): 1055-1060 doi: $10.25083 / \mathrm{rbl} / 24.6 / 1055.1060$

Received for publication, January, 6, 2018

Accepted, May, 4, 2018

Original paper

\title{
The influence of climatic factors on the main phenological phases of grapevines from Stefanesti Viticultural Center, Romania
}

\author{
ELENA-COCUTA BUCIUMEANU ${ }^{1}$, GABRIEL MURARIU ${ }^{2}$ LUCIAN DINCĂ ${ }^{3}$, \\ DIANA ELENA VIZITIU ${ }^{1 *}$, LUCIAN PUIU GEORGESCU ${ }^{2}$
}

${ }^{1}$ National Research and Development Institute for Biotechnology in Horticulture, Stefanesti Arges, Stefanesti City, Bucharest - 37 Pitesti Road, Arges, 117715, 0248266714, vizitiud@yahoo.com, Romania

2“"Dunărea de Jos" University of Galaţi, Faculty of Sciences and Environment, Chemistry, Physics and Environment Department, gmurariu@ugal.ro, Romania,

3“Marin Drăcea" National Institute of Research and Development in Forestry, dinka.lucian@ gmail.com, Romania

\begin{abstract}
The growth and development of grapevine plants depend on climatic and orographic factors. The influence of these factors on plants creates a strong connection with environmental factors. The main purpose of this paper was to assess the climatic factors' level of influence on the grapevine phenophases from the Stefanesti area by using statistical methods less frequently used in the literature. The database we used is consistent and includes climatic factor from the period between 1989 and 2017. This MANOVA multi-factorial statistical analysis also included parameters that are less frequently encountered in the literature, such as the Huglin index or the number of days with precipitation levels higher than a reference level. The results showed that the blooming of the studied grapevine varieties depends primarily on the average annual temperature, the average of maximum temperatures, precipitation values, and the number of days with precipitation levels exceeding $10 \mathrm{~mm}$.
\end{abstract}

Keywords Climate, management, flowering, veraison, ripening.

To cite this article: BUCIUMEANU E-C, MURARIU G, DINCĂ L, VIZITIU DE, GEORGESCU LP. The influence of climatic factors on the main phenological phases of grapevines from Stefanesti Viticultural Center, Romania. Rom Biotechnol Lett. 2019; 24(6): 1055-1060. DOI: $10.25083 / \mathrm{rbl} / 24.6 / 1055.1060$

$\square *$ Corresponding author: DIANA ELENA VIZITIU, National Research and Development Institute for Biotechnology in Horticulture, Stefanesti Arges, Stefanesti City, Bucharest - 37 Pitesti Road, Arges, 117715, Romania; Phone: 0248266714

E-mail: vizitiud@yahoo.com 


\section{Introduction}

The grapevine and wine industries have been rapidly evolving in recent years. This is correlated with research and results in the literature that take into account geographical characteristics, including the topo-climate (MAHEIRO \& al [1]; OLTEANU [2]; BUTIUC-KEUL \& al [3]). In reality, Vitis vinifera L. represents one of the oldest perennial cultures (GHAFFARI \& FERCHICHI [4]), whose vegetative cycle, morphologically described through phenological stages, is predominantly determined by air temperature (OLTEANU [2]; TSANTOUKA \& al [5]). Precipitation levels, soil properties, and radiation are furthermore important, but to a lesser degree (OLTEANU [2]; PERKOULIDIS \& al [6]).

In general, the process is easy to describe. After a winter period with low temperatures, the vegetation season begins with a spring warming. The specialty literature recognizes the essential character of the cumulative effect posed by temperatures over $10^{\circ} \mathrm{C}$ (basic temperature). This represents an essential thermic request that guarantees the apparition of the above-mentioned event (WINKLER \& al [7]; COLA \& al [8]). The principal subsequent stages are flowering, veraison, and maturity, followed by harvesting. During this final stage, the role played by warm temperatures and dry stable atmospheric conditions represents an essential aspect for increasing culture productiveness and wine quality (JONES \& DAVIS [9]; SANTOS \& al [10]).

Low temperatures and the total number of instances of precipitation in the latent period are essential for the subsequent growth season (SANTOS \& al [10]; MURARIU \& al [11]; KLIEWER [12]; RADULESCU \& al [13]). Regardless of important regional differences, the strong inter-annual variability of climatic conditions can significantly influence grapevine phenology (MURARIU \& al [11]; RADULESCU \& al [13]). Furthermore, the calendar of each phenological phase differs based on each grapevine variety and is generally linked with local thermic conditions (PARKER \& al [14]). Indeed, phenological models based on temperature accumulations higher than the reference temperature have been widely reported in studies (KLIEWER [12]; RADULESCU \& al [13]; PARKER \& al [14]). Complex models have also been developed by using different threshold values (PARKER $\&$ al [14]). A number of studies have shown that high temperatures are associated with the early phenological development of plants (COLA \& al [8]; RADULESCU \& al [13], FRAGA \& al [15]).

Based on the phenological phase, the highest consumption of water is recorded during the maximum sprout and grapevine growth stages, while the lowest consumption recorded occurs between the beginning of weeping and flowering (OLTEANU [2]; RADULESCU \& al [13]; OSLOBEANU \& al [16]; ALEXANDRESCU \& al [17]). The sufficient physiological temperature, in conditions of optimum temperature, activates the flowering.
The primary purpose of the present paper was to evaluate the influence of climatic factors on the main phenological phases of grapevines from the Stefanesti viticultural centre. The predominant method used for this study was ANOVA multi-factorial analysis, a procedure rarely used in the specialty literature. Furthermore, due to the consistent character of the database used, we were able to achieve a systematic analysis, introducing all the climatic factors frequently used in the literature.

\section{Materials and Methods}

The studies were realized in the period between 1997 and 2017 in the Stefanesti viticultural centre located in Romania, on the platforms and hill slopes from the southern part of Muntenia's Sub Carpathians. A multitude of soils can be found here, both in their natural placement and in anthropic profiles disturbed by management and hill-levelling works. Due to the wrestled relief, the soils are distributed in soil complexes: Regosols, Aluviosols, Eutricambisols, Preluvisols, Luvisols, Planosols, or Antrosols (DINCA \& al [18]; SPARCHEZ \& al [19]; CRISAN \& al [20]).

During the vegetation stage, the grapevine situated in the fructification stage undergoes more phenological stages that influence the growth, development, and fructification processes. The present study followed the evolution of the principal phenological stages (flowering, blooming, ripening, and grape maturation) for eight species: Perlette, Muscat d'Adda, Feteasca alba, Muscat Ottonel, Pinot gris, Cabernet Sauvignon, Burgund, and Merlot.

The data were statistically analysed using Statsoft Statistica 13 software. The ANOVA method studies the variation in the dataset, while the work method used within this article (the multi-factorial ANOVA method) investigates the influence of each factor included by analysing and establishing the percentage and importance of each parameter based on the analysed dataset. As is already known, by evaluating the variation between the parameter groups, the multi-factorial method can identify the set of significant parameters and can appraise the percentage value for each parameter for a multidimensional linear model. The significance threshold was set at $\mathrm{p}=0.05$.

\section{Results and Discussions}

\section{Analysing the climatic parameters and their influence on the grapevines from Stefanesti}

The predominant climatic conditions from the studied period were analysed. As such, based on the entire recording period offered by Goleasca meteorological station (44 $51^{\prime} \mathrm{N}$ and $24^{\circ} 57^{\prime} \mathrm{E}$ ) in Stefanesti Viticultural Areal, Argeș County, we were able to analyse the average monthly values of the air temperature for a period of 26 years, namely, between 1989 and 2017 (Fig. 1a). The following data were then represented as box-plot diagrams: average annual temperatures, the number of days 
with precipitation levels higher than the reference threshold, Huglin index values, and the sum of temperatures from the vegetation period. Each diagram includes the ANOVA analysis results, which clearly emphasize the time variation for each measurement, followed by a representation of tendencies established by the statistical analysis.
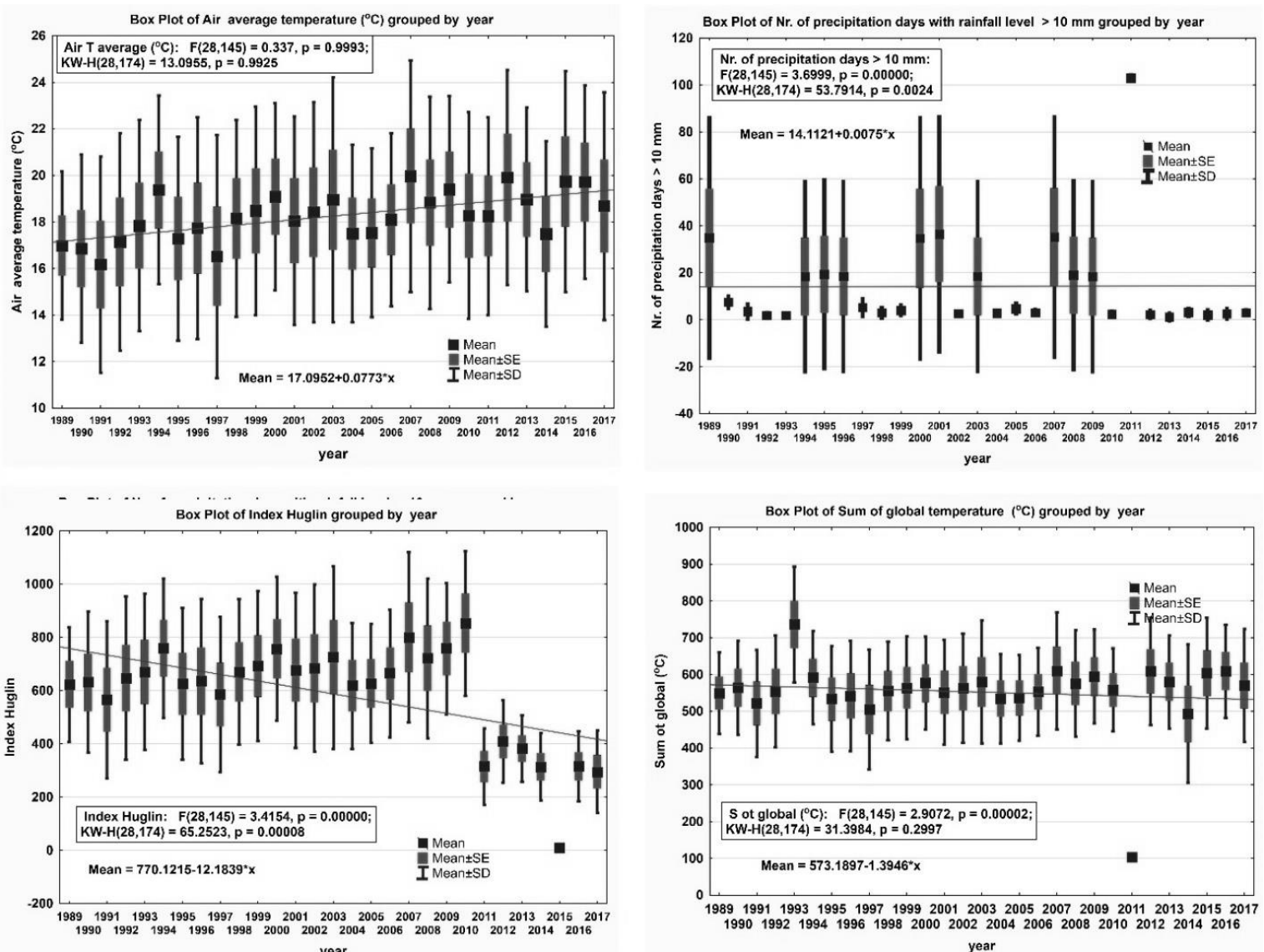

Figure 1. Box-plot representation for: (a) - average annual temperatures in the Stefanesti viticultural area, (b) - the number of days with precipitation levels exceeding $10 \mathrm{~mm},(\mathbf{c})$ - average annual values of the Huglin index in the Stefanesti viticultural area, (d) - the sum of air temperatures from the Stefanesti viticultural area
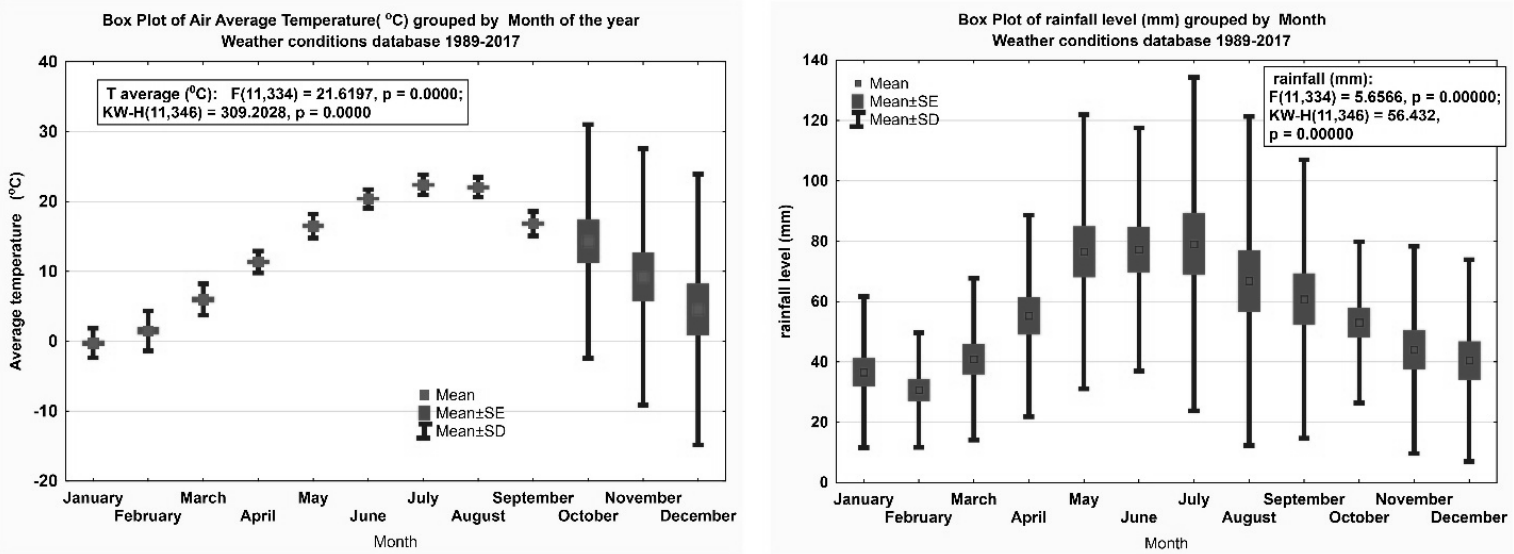

Figure 2. Box-plot representation for the average monthly air temperatures and precipitation values from the Stefanesti viticultural area

An increase in annual average temperatures can be observed in this area for the period between 1989 and 2017. This increase is situated within the general globalwarming tendencies, however, and has an impact on the advancement and decreasing of the phenological phases development period (KUHN \& al [21]). On the other hand, the annual number of days with precipitation levels higher than $10 \mathrm{~mm}$ remained constant throughout the analysed 
period. This fact suggests that the viticultural area studied ensures an optimum humidity for grapevine growth and fructification processes.

The Huglin index strongly decreases, mostly due to the values recorded more recently (between the years of 2011 and 2017). The monthly variation in the average temperatures and precipitation levels from the Stefanesti-Arges area is of a Gaussian type: the maximum temperatures were recorded in July and August, and the minimum temperatures were recorded in January; meanwhile, high temperature variations were recorded between the months of October and December, followed by maximum precipitation levels in the months of May and June, minimum precipitation levels in the months of January and February, and high variation in precipitation levels recorded in all months. As a result, grapevine culture is possible in this area, as the minimum temperatures occurring in winter do not negatively affect the viability of buds. Nevertheless, this fact imposes a need for continuous monitoring of climatic factors as well as measurements with regards to their influence on the grapevine phenological phases.

\section{The influence of climate on the phenological phases of grapevines from Stefanesti}

A multi-linear effect analysis example is rendered in Table 1.

Table 1. Multi-linear effect analysis - flowering phenological phase - during the month of April

\begin{tabular}{|c|c|c|c|c|c|c|c|c|c|}
\hline April month & & \multicolumn{2}{|c|}{ PE } & \multicolumn{2}{|c|}{ MA } & \multicolumn{2}{|c|}{ FA } & \multicolumn{2}{|c|}{ MO } \\
\hline Effect & $\begin{array}{l}\text { Degr. of } \\
\text { Freedom }\end{array}$ & $\begin{array}{l}\text { Wald } \\
\text { Stat. }\end{array}$ & $\mathrm{p}$ & $\begin{array}{l}\text { Wald } \\
\text { Stat. }\end{array}$ & $\mathrm{p}$ & $\begin{array}{l}\text { Wald } \\
\text { Stat. }\end{array}$ & $\mathrm{p}$ & $\begin{array}{l}\text { Wald } \\
\text { Stat. }\end{array}$ & $\mathrm{p}$ \\
\hline Intercept & 1 & $\begin{array}{c}8.7260 \\
91\end{array}$ & $\begin{array}{c}0.0031 \\
37\end{array}$ & $\begin{array}{r}5.0518 \\
74 \\
\end{array}$ & $\begin{array}{r}0.0245 \\
99 \\
\end{array}$ & $\begin{array}{r}2.0612 \\
40 \\
\end{array}$ & $\begin{array}{r}0.1510 \\
87 \\
\end{array}$ & $\begin{array}{r}2.79786 \\
8\end{array}$ & $\begin{array}{r}0.0943 \\
90 \\
\end{array}$ \\
\hline T average $\left({ }^{\circ} \mathrm{C}\right)$ & 1 & $\begin{array}{c}4.6508 \\
35\end{array}$ & $\begin{array}{c}0.0310 \\
38\end{array}$ & $\begin{array}{r}1.5498 \\
54\end{array}$ & $\begin{array}{r}0.2131 \\
57\end{array}$ & $\begin{array}{r}0.2870 \\
25\end{array}$ & $\begin{array}{r}0.5921 \\
33\end{array}$ & $\begin{array}{r}0.35033 \\
7\end{array}$ & $\begin{array}{r}0.5539 \\
23\end{array}$ \\
\hline $\mathrm{T}$ min. average $\left({ }^{\circ} \mathrm{C}\right)$ & 1 & $\begin{array}{c}0.5570 \\
59\end{array}$ & $\begin{array}{c}0.4554 \\
48\end{array}$ & $\begin{array}{r}0.0647 \\
93\end{array}$ & $\begin{array}{r}0.7990 \\
75\end{array}$ & $\begin{array}{r}0.1386 \\
70\end{array}$ & $\begin{array}{r}0.7096 \\
06\end{array}$ & $\begin{array}{r}0.10229 \\
5\end{array}$ & $\begin{array}{r}0.7490 \\
93\end{array}$ \\
\hline $\mathrm{T}$ max. average $\left({ }^{\circ} \mathrm{C}\right)$ & 1 & $\begin{array}{c}3.6713 \\
75\end{array}$ & $\begin{array}{c}0.0553 \\
55\end{array}$ & $\begin{array}{r}3.8819 \\
00\end{array}$ & $\begin{array}{r}0.0488 \\
09\end{array}$ & $\begin{array}{r}2.8078 \\
96\end{array}$ & $\begin{array}{r}0.0938 \\
01\end{array}$ & $\begin{array}{r}3.56083 \\
0\end{array}$ & $\begin{array}{r}0.0591 \\
58\end{array}$ \\
\hline April month & & \multicolumn{2}{|c|}{ PG } & \multicolumn{2}{|c|}{ CS } & \multicolumn{2}{|c|}{ B } & \multicolumn{2}{|c|}{ ME } \\
\hline Effect & $\begin{array}{l}\text { Degr. of } \\
\text { Freedom }\end{array}$ & $\begin{array}{l}\text { Wald } \\
\text { Stat. }\end{array}$ & $\mathrm{p}$ & $\begin{array}{l}\text { Wald } \\
\text { Stat. }\end{array}$ & $\mathrm{p}$ & $\begin{array}{l}\text { Wald } \\
\text { Stat. }\end{array}$ & $\mathrm{p}$ & $\begin{array}{l}\text { Wald } \\
\text { Stat. }\end{array}$ & $\mathrm{p}$ \\
\hline Annual rainfall (mm) & 1 & $\begin{array}{c}6.4136 \\
94\end{array}$ & $\begin{array}{c}0.0113 \\
24\end{array}$ & $\begin{array}{r}2.8112 \\
29 \\
\end{array}$ & $\begin{array}{r}0.0936 \\
07\end{array}$ & $\begin{array}{r}0.5124 \\
61\end{array}$ & $\begin{array}{r}0.4740 \\
76 \\
\end{array}$ & $\begin{array}{r}0.38288 \\
5\end{array}$ & $\begin{array}{r}0.5360 \\
63 \\
\end{array}$ \\
\hline $\begin{array}{l}\text { flowering period } \\
\text { Rainfall }(\mathrm{mm})\end{array}$ & 1 & $\begin{array}{c}6.0465 \\
90\end{array}$ & $\begin{array}{c}0.0139 \\
33\end{array}$ & $\begin{array}{r}2.7559 \\
97\end{array}$ & $\begin{array}{r}0.0968 \\
90\end{array}$ & $\begin{array}{r}0.5442 \\
40\end{array}$ & $\begin{array}{r}0.4606 \\
81\end{array}$ & $\begin{array}{r}0.36421 \\
5\end{array}$ & $\begin{array}{r}0.5461 \\
75\end{array}$ \\
\hline $\begin{array}{l}\text { flowering period } \\
\text { Index Huglin }\end{array}$ & 1 & $\begin{array}{c}3.4444 \\
87\end{array}$ & $\begin{array}{c}0.0634 \\
63\end{array}$ & $\begin{array}{r}2.8877 \\
41 \\
\end{array}$ & $\begin{array}{r}0.0892 \\
56 \\
\end{array}$ & $\begin{array}{r}2.6278 \\
08 \\
\end{array}$ & $\begin{array}{r}0.1050 \\
07 \\
\end{array}$ & $\begin{array}{r}3.30441 \\
7\end{array}$ & $\begin{array}{r}0.0690 \\
94 \\
\end{array}$ \\
\hline $\begin{array}{l}\text { flowering period - No } \\
\text { of precipitation days } \\
10 \mathrm{~mm}\end{array}$ & 1 & $\begin{array}{c}6.8895 \\
71\end{array}$ & $\begin{array}{c}0.0086 \\
70\end{array}$ & $\begin{array}{r}4.8272 \\
59\end{array}$ & $\begin{array}{r}0.0280 \\
13\end{array}$ & $\begin{array}{r}4.7371 \\
40\end{array}$ & $\begin{array}{r}0.0295 \\
18\end{array}$ & $\begin{array}{r}3.81096 \\
2\end{array}$ & $\begin{array}{r}0.0509 \\
18\end{array}$ \\
\hline $\begin{array}{l}\text { flowering period } \mathrm{S} \text { ot } \\
\text { global }(\mathrm{oC})\end{array}$ & 1 & $\begin{array}{c}0.2448 \\
63\end{array}$ & $\begin{array}{c}0.6207 \\
16\end{array}$ & $\begin{array}{r}0.0001 \\
26 \\
\end{array}$ & $\begin{array}{r}0.9910 \\
50 \\
\end{array}$ & $\begin{array}{r}1.1279 \\
36 \\
\end{array}$ & $\begin{array}{r}0.2882 \\
16 \\
\end{array}$ & $\begin{array}{r}1.29572 \\
3\end{array}$ & $\begin{array}{r}0.2549 \\
96 \\
\end{array}$ \\
\hline $\begin{array}{l}\text { flowering period } \mathrm{S} \text { ot } \\
\text { active }(\mathrm{oC})\end{array}$ & 1 & $\begin{array}{c}2.3187 \\
10\end{array}$ & $\begin{array}{c}0.1278 \\
26\end{array}$ & $\begin{array}{r}1.3358 \\
91\end{array}$ & $\begin{array}{r}0.2477 \\
60\end{array}$ & $\begin{array}{r}0.0233 \\
69\end{array}$ & $\begin{array}{r}0.8785 \\
02\end{array}$ & $\begin{array}{r}0.03580 \\
4\end{array}$ & $\begin{array}{r}0.8499 \\
21\end{array}$ \\
\hline Intercept & 1 & $\begin{array}{r}0.5540 \\
16 \\
\end{array}$ & $\begin{array}{r}0.4566 \\
81 \\
\end{array}$ & $\begin{array}{r}1.1778 \\
16 \\
\end{array}$ & $\begin{array}{r}0.2778 \\
01 \\
\end{array}$ & $\begin{array}{r}0.8936 \\
87 \\
\end{array}$ & $\begin{array}{r}0.3444 \\
80 \\
\end{array}$ & $\begin{array}{r}1.42042 \\
5 \\
\end{array}$ & $\begin{array}{r}0.2333 \\
33 \\
\end{array}$ \\
\hline T average $\left({ }^{\circ} \mathrm{C}\right)$ & 1 & $\begin{array}{r}0.2584 \\
53 \\
\end{array}$ & $\begin{array}{r}0.6111 \\
85\end{array}$ & $\begin{array}{r}2.3031 \\
83\end{array}$ & $\begin{array}{r}0.1291 \\
09\end{array}$ & $\begin{array}{r}0.1325 \\
02\end{array}$ & $\begin{array}{r}0.7158 \\
51\end{array}$ & $\begin{array}{r}2.20171 \\
5\end{array}$ & $\begin{array}{r}0.1378 \\
57\end{array}$ \\
\hline $\mathrm{T}$ min. average $\left({ }^{\circ} \mathrm{C}\right)$ & 1 & $\begin{array}{r}0.1403 \\
50\end{array}$ & $\begin{array}{r}0.7079 \\
33\end{array}$ & $\begin{array}{r}0.5818 \\
41\end{array}$ & $\begin{array}{r}0.4455 \\
92\end{array}$ & $\begin{array}{r}0.0452 \\
25\end{array}$ & $\begin{array}{r}0.8315 \\
90\end{array}$ & $\begin{array}{r}0.75202 \\
2\end{array}$ & $\begin{array}{r}0.3858 \\
37\end{array}$ \\
\hline $\mathrm{T}$ max. average $\left({ }^{\circ} \mathrm{C}\right)$ & 1 & $\begin{array}{r}0.4092 \\
97\end{array}$ & $\begin{array}{r}0.5223 \\
26\end{array}$ & $\begin{array}{r}1.7493 \\
82\end{array}$ & $\begin{array}{r}0.1859 \\
54\end{array}$ & $\begin{array}{r}3.3648 \\
35\end{array}$ & $\begin{array}{r}0.0666 \\
02\end{array}$ & $\begin{array}{r}1.71486 \\
8\end{array}$ & $\begin{array}{r}0.1903 \\
55\end{array}$ \\
\hline Annual rainfall (mm) & 1 & $\begin{array}{r}0.9031 \\
72 \\
\end{array}$ & $\begin{array}{r}0.3419 \\
33\end{array}$ & $\begin{array}{r}0.0794 \\
63 \\
\end{array}$ & $\begin{array}{r}0.7780 \\
27\end{array}$ & $\begin{array}{r}0.4687 \\
68\end{array}$ & $\begin{array}{r}0.4935 \\
54\end{array}$ & $\begin{array}{r}0.07764 \\
4\end{array}$ & $\begin{array}{r}0.7805 \\
16\end{array}$ \\
\hline $\begin{array}{l}\text { flowering period } \\
\text { Rainfall }(\mathrm{mm})\end{array}$ & 1 & $\begin{array}{r}0.9772 \\
14 \\
\end{array}$ & $\begin{array}{r}0.3228 \\
88 \\
\end{array}$ & $\begin{array}{r}0.5497 \\
53 \\
\end{array}$ & $\begin{array}{r}0.4584 \\
19 \\
\end{array}$ & $\begin{array}{r}0.5105 \\
83 \\
\end{array}$ & $\begin{array}{r}0.4748 \\
86 \\
\end{array}$ & $\begin{array}{r}0.68873 \\
9 \\
\end{array}$ & $\begin{array}{r}0.4065 \\
93 \\
\end{array}$ \\
\hline $\begin{array}{l}\text { flowering period } \\
\text { Index Huglin }\end{array}$ & 1 & $\begin{array}{r}1.0488 \\
53 \\
\end{array}$ & $\begin{array}{r}0.3057 \\
71 \\
\end{array}$ & $\begin{array}{r}4.2996 \\
64 \\
\end{array}$ & $\begin{array}{r}0.0381 \\
20 \\
\end{array}$ & $\begin{array}{r}3.3700 \\
46 \\
\end{array}$ & $\begin{array}{r}0.0663 \\
92 \\
\end{array}$ & $\begin{array}{r}4.45871 \\
9 \\
\end{array}$ & $\begin{array}{r}0.0347 \\
24 \\
\end{array}$ \\
\hline $\begin{array}{l}\text { flowering period - No } \\
\text { of precipitation days } \\
10 \mathrm{~mm}\end{array}$ & 1 & $\begin{array}{r}4.6971 \\
12\end{array}$ & $\begin{array}{r}0.0302 \\
13\end{array}$ & $\begin{array}{r}6.6143 \\
91\end{array}$ & $\begin{array}{r}0.0101 \\
16\end{array}$ & $\begin{array}{r}2.4244 \\
02\end{array}$ & $\begin{array}{r}0.1194 \\
59\end{array}$ & $\begin{array}{r}6.93465 \\
6\end{array}$ & $\begin{array}{r}0.0084 \\
54\end{array}$ \\
\hline $\begin{array}{l}\text { flowering period } \mathrm{S} \text { ot } \\
\text { global }(\mathrm{oC})\end{array}$ & 1 & $\begin{array}{r}1.4281 \\
42\end{array}$ & $\begin{array}{r}0.2320 \\
68\end{array}$ & $\begin{array}{r}0.7973 \\
63 \\
\end{array}$ & $\begin{array}{r}0.3718 \\
83\end{array}$ & $\begin{array}{r}1.3833 \\
77\end{array}$ & $\begin{array}{r}0.2395 \\
27\end{array}$ & $\begin{array}{r}0.69520 \\
9\end{array}$ & $\begin{array}{r}0.4043 \\
98\end{array}$ \\
\hline $\begin{array}{l}\text { flowering period } \mathrm{S} \text { ot } \\
\text { active }(\mathrm{oC})\end{array}$ & 1 & $\begin{array}{r}0.1537 \\
92\end{array}$ & $\begin{array}{r}0.6949 \\
38\end{array}$ & $\begin{array}{r}1.1898 \\
75\end{array}$ & $\begin{array}{r}0.2753 \\
55\end{array}$ & $\begin{array}{r}0.5682 \\
01\end{array}$ & $\begin{array}{r}0.4509 \\
75\end{array}$ & $\begin{array}{r}1.11398 \\
9\end{array}$ & $\begin{array}{r}0.2912 \\
17\end{array}$ \\
\hline
\end{tabular}

PE - Perlette, MA - Muscat d'Adda, FA - Feteasca alba, MO - Muscat Ottonel, PG - Pinot gris, CS - Cabernet Sauvignon, $\mathrm{B}$ - Burgund, ME - Merlot. 
The blooming of the studied grapevine varieties was achieved differently, based on certain climatic parameters. As such, the Perlette variety's blooming was influenced by average temperatures, precipitation levels, and the number of days with precipitation levels higher than $10 \mathrm{~mm}$; meanwhile, the Muscat d'Adda variety's blooming was influenced by the average of the maximum temperatures and the number of days with precipitation levels higher than $10 \mathrm{~mm}$. The Feteasca alba and Pinot gris varieties' blooming was influenced primarily by the number of days with precipitation levels higher than $10 \mathrm{~mm}$, while the Cabernet Sauvignon and Merlot varieties' blooming was influenced by the Huglin index as well as the number of days with precipitation levels higher than $10 \mathrm{~mm}$. The blooming of the Muscat Ottonel and Burgund varieties, however, was not significantly influenced by climatic parameters (Table 1).

The time interval in which the phenological phases manifest can affect the dynamic of plant metabolites (KUHN \& al [21]; MARTINEZ-LUSCHER \& al [22]), while temperature and water deficits can advance the start of grapevine phenological phases. As a consequence, it is important to establish the effect of climatic factors on the phenological phases of plants in order to elaborate viticultural strategies (MARTINEZ-LUSCHER \& al [22]).

For certain species, the start of the blooming phenological phase depends more on the average annual temperature, especially on the number of days with temperatures higher than $10^{\circ} \mathrm{C}(\mathrm{p}<0.05)$. For the veraison phenological phase, an essential parameter is the Huglin index $(\mathrm{p}<0.05)$, while the maturation phase is represented by the sum of useful temperature degrees (useful thermic balance) accumulating up to that moment.

From a statistical point of view, an appropriate level of consistency can be observed in the method presented. If for the starting phenological phases, the sensitive parameters are the ones associated with air temperature and precipitation levels, for the final phenological phases, all the climatic parameters, including the auxiliary ones defined by the literature, have a more important influence. This phenomenon, which has been observed by a string of authors, emphasizes the perfectly functional character in the case of systematically applying the method presented.

Furthermore, the method is sensitive to the phenological stage studied, such that the sensitivity determined for the entrance measurements is certainly different to the sensitivity determined for the same set of parameters (Table 1). Due to the consistency and massive size of the database used, significant differences were determined between the different types of species studied. Moreover, the categories with a higher sensitivity towards the variability in meteorological factors can also be identified.

\section{Conclusions}

The multi-linear analysis method is a global method that facilitates establishing the sensitivity of different grapevine varieties to climatic parameters. Although this method has seldom been used in the specialty literature, it proved highly efficient. Furthermore, the specific character of each variety can be observed relatively easily, as can the particular influence of environmental factors on each studied variety. The start of the blooming phenological phase for the studied grapevine varieties was primarily dependent on the average annual temperature, the average maximum temperatures, precipitation levels, and the number of days with precipitation levels higher than $10 \mathrm{~mm}$.

\section{Acknowledgement}

This article is based upon work from 6PCCDI Research project: "Increasing the institutional bio economic research capacity for innovative exploitation of local plant resources to obtain horticultural products with high added value", supported by the Executive Unit for Financing Higher Education, Research, Development and Innovation (UEFISCDI), Romania (2018-2020).

\section{References}

1. MALHEIRO AC, CAMPOS R, FRAGA H, EIRASDIAS J et al. Winegrape Phenology and Temperature Relationships in the Lisbon Wine Region, Portugal. J Int Sci Vigne Vin. 2013; 47(4): 287-299.

2. OLTEANU I. General viticulture, Universitaria Publishing House, Craiova. 2000.

3. Butiuc-Keul AL, Coste A, Craciunas C. Molecular characterization and in vitro preservation of some grapevine cultivars. Rom Biotech Lett. 2011; 16(3): 6226-6233.

4. GHAFFARI S, FERCHICHI A. Characterization of Tunisian grapevine (Vitis vinifera L.) cultivars using leaves morphological traits and mineral composition. Rom Biotech Lett. 2011; 16(5): 6556-6563.

5. TSANTOUKA M, GEROMOSHOS D, GOLUMBEANU M. Agrotouristic Development in the Area of 'Nymfeo' - Florina, Greece. J Environ Prot Ecol. 2003; 4 (1): 160.

6. PERKOULIDIS G, KARAGIANNIDIS A, PHILIPPOPOULOS N, MALAMAKIS A. Biomass Energy Recovery in Hellenic Wood Production Facilities. J Environ Prot Ecol. 2011; 2: 603-610.

7. WINKLER AJ, COOK JA, KLIEWER WM, LIDER LA. General Viticulture. University of California Press, USA. 1974.

8. COLA G, FAILlA O, MAGHRADZE D, MEGRELIDZE L et al. Grapevine phenology and climate change in Georgia. Int J Biometeorol. 2017; 61(4): 761-773.

9. JONES GV, DAVIS RE. Using a synoptic climatological approach to understand climate viticulture relationships. Int J Climatol. 2000; 20: 813-837.

10. SANTOS JA, MALHEIRO AC, KARREMANN MK, PINTO JG. Statistical modelling of grapevine yield in the Port Wine region under present and future climate conditions. Int J Biometeorol. 2011; 55: 119-131

11. MURARIU G, HAHUIE V, MURARIU AGL, GEORGESCU L et al. Growth Rate Modeling for 
White Poplar in the South Eastern Part of Romania: An Important Issue of Forest Conservation, IJCS. 2017; 8(2): 303-316.

12. KLIEWER WM. Effect of high temperatures during the bloom-set period on fruit-set, ovule fertility and berry growth on several grape cultivars. Am J Enol Vitic. 1977; 28: 215-222.

13. RADULESCU I, POPA C, VIZITIU D, ONACHE A et al. Strengthening brand "Wine of Stefanesti" by extending in culture a new clones: Feteasca Alba $97 \mathrm{St}$. and Feteasca regala 72 St. for white wine, and for red wine Feteasca neagra 6 St. Scientific papers, B Series, Horticulture. 2010; Vol. LIV: 589-595. Invel Multimedia Publishing House.

14. PARKER AK, GARCIA DE CORTAZAR ATAURI I, VAN LEEUWEN C, CHUINE I. General phenological model to characterise the timing of flowering and veraison of Vitis vinifera L. Aust J Grape Wine Res. 2011; 17: 206-216.

15. FRAGA H, MALHEIRO AC, MOUTINHOPEREIRA J, SANTOS JA. Future scenarios for viticultural zoning in Europe: ensemble projections and uncertainties. Int J Biometeorol. 2013; 57: 909-925.

16. OSLOBEANU M, MACICI M, GEORGESCU M, STOIAN V. Zonarea soiurilor de vita de vie in Romania. Ceres Publishing House, Bucharest. 1991.
17. ALEXANDRESCU I, OSLOBEANU M, JIANU L, PITUC P. The little encyclopedia from viticulture. Glasul Bucovinei Publishing House, Iasi. 1994.

18. DINCĂ L, SPARCHEZ G, DINCĂ M. Romanian's forest soil GIS map and database and their ecological implications. Carpath J Earth Env. 2014; 9(2), 133-142.

19. SPÂRCHEZ G, DINCĂ L, MARIN G, DINCĂ M, ENESCU RE. Variation of eutric cambisols' chemical properties based on altitudinal and geomorphological zoning. Environ Eng Manag J. 2017; 16(12): 2911-2918.

20. CRIȘAN V, DINCĂ L, ONEȚ A, ONEȚ C. The description of forest soils from Braila county. Natural Resources and Sustainable Development. 2017; 7: 21-26.

21. KUHN N, GUAN L, DAI ZW, WU BH et al. Berry ripening: recently heard through the grapevine. $J$ Exp Bot. 2014; 65: 4543-4559.

22. MARTINEZ-LUSCHER J, SANCHEZ-DIAZ M, DELROT S, AGUIRREOLEA J et al. Ultraviolet-B alleviates the uncoupling effect of elevated $\mathrm{CO}$ and increased temperature on grape berry (Vitis vinifera $\mathrm{cv}$. Tempranillo) anthocyanin and sugar accumulation. Aust J Grape Wine Res. 2016; 22: 87-95. 